University of Nebraska - Lincoln

DigitalCommons@University of Nebraska - Lincoln

Faculty Papers and Publications in Animal

Science

Animal Science Department

2019

\title{
Evaluation of the effects of biochar on diet digestibility and methane production from growing and finishing steers
}

\author{
Thomas Winders \\ University of Nebraska-Lincoln, thomas.winders@huskers.unl.edu \\ Melissa L. Jolly \\ University of Nebraska Lincoln, mjolly@huskers.unl.edu \\ Hannah C. Wilson \\ University of Nebraska-Lincoln, hhamilton6@unl.edu \\ James C. MacDonald \\ University of Nebraska-Lincoln, jmacdonald2@unl.edu \\ Galen E. Erickson \\ University of Nebraska - Lincoln, gerickson4@unl.edu
}

See next page for additional authors

Follow this and additional works at: https://digitalcommons.unl.edu/animalscifacpub

Part of the Genetics and Genomics Commons, and the Meat Science Commons

Winders, Thomas; Jolly, Melissa L.; Wilson, Hannah C.; MacDonald, James C.; Erickson, Galen E.; and Watson, Andrea K., "Evaluation of the effects of biochar on diet digestibility and methane production from growing and finishing steers" (2019). Faculty Papers and Publications in Animal Science. 1105.

https://digitalcommons.unl.edu/animalscifacpub/1105

This Article is brought to you for free and open access by the Animal Science Department at DigitalCommons@University of Nebraska - Lincoln. It has been accepted for inclusion in Faculty Papers and Publications in Animal Science by an authorized administrator of DigitalCommons@University of Nebraska Lincoln. 


\section{Authors}

Thomas Winders, Melissa L. Jolly, Hannah C. Wilson, James C. MacDonald, Galen E. Erickson, and Andrea K. Watson 


\title{
Evaluation of the effects of biochar on diet digestibility and methane production from growing and finishing steers
}

\author{
Thomas M. Winders, Melissa L. Jolly-Breithaupt, Hannah C. Wilson, James C. MacDonald, \\ Galen E. Erickson, and Andrea K. Watson ${ }^{1}$
}

Department of Animal Science, University of Nebraska-Lincoln, Lincoln, NE 68583-0908

\begin{abstract}
The objectives of these studies were to evaluate the effects of biochar $(0 \%, 0.8 \%$, or $3 \%$ of diet dry matter) on diet digestibility and methane and carbon dioxide production from cattle on growing and finishing diets. The growing diet consisted of $21 \%$ brome hay, $20 \%$ wheat straw, $30 \%$ corn silage, $22 \%$ wet distillers grains plus solubles, and $7 \%$ supplement. The finishing diet consisted of $53 \%$ dry-rolled corn, $15 \%$ corn silage, $25 \%$ wet distillers grains plus solubles, and 7\% supplement. In both trials biochar replaced fine ground corn in the supplement. Six crossbred steers (initial body weight [BW] $529 \mathrm{~kg} ; \mathrm{SD}=16 \mathrm{~kg}$ ) were used in both the growing and finishing trial. The growing diets were evaluated over 6 periods followed by the finishing trial with 3 periods. Digestibility measures were taken over $4 \mathrm{~d}$ after at least $8 \mathrm{~d}$ of adaptation to diets followed by $2 \mathrm{~d}$ of gas emission measurements using headbox calorimeters. Dry matter intake (DMI) was not affected $(P \geq 0.43 ; 7.91 \mathrm{~kg} / \mathrm{d})$ by biochar inclusion in the growing study and increased quadratically $(P=0.07)$ in the finishing study with $0.8 \%$ biochar inclusion having the greatest DMI (12.9 kg/d). Organic matter (OM) and neutral detergent fiber (NDF) digestibility increased
\end{abstract}

quadratically $(P=0.10)$ in the growing study whereas OM digestibility tended to linearly decrease $(P=0.13)$ and NDF digestibility was not affected $(P \geq 0.39)$ by biochar inclusion in the finishing diet. Digestible energy intake (Mcal/d) was not affected $(P \geq 0.25)$ by biochar inclusion in the growing or finishing study. Methane production $(\mathrm{g} / \mathrm{d})$ tended to decrease quadratically $(P=0.14)$ in the growing study and was decreased $10.7 \%$ for the $0.8 \%$ biochar treatment relative to the control. There were no statistical differences in methane production $(\mathrm{g} / \mathrm{d})$ in the finishing study $(P \geq 0.32)$ but cattle on the $0.8 \%$ biochar treatment produced numerically less $(9.6 \%)$ methane than the control. Methane production as $\mathrm{g} / \mathrm{kg}$ DMI of the $0.8 \%$ biochar treatment relative to the control was numerically reduced $9.5 \%$ and $18.4 \%$ in the growing and finishing studies, respectively $(P \geq 0.13)$. Carbon dioxide production $(\mathrm{g} / \mathrm{d}$ and $\mathrm{g} / \mathrm{kg}$ of intake) quadratically decreased $(P \leq$ $0.06)$ in the growing study but was not affected by treatment in the finishing study $(P \geq 0.34)$. Although biochar is not a U.S. Food and Drug Administration -approved feed for cattle, the initial research shows potential as a methane mitigation strategy in both growing and finishing diets.

Key words: beef cattle, biochar, digestibility, methane

(C) The Author(s) 2019. Published by Oxford University Press on behalf of the American Society of Animal Science.

This is an Open Access article distributed under the terms of the Creative Commons Attribution Non-Commercial License (http://creativecommons.org/licenses/by-nc/4.0/), which permits non-commercial re-use, distribution, and reproduction in any medium, provided the original work is properly cited. For commercial re-use, please contact journals.permissions@oup.com

Transl. Anim. Sci. 2019.3:775-783 doi: $10.1093 / \operatorname{tas} / \operatorname{txz} 027$

\section{INTRODUCTION}

${ }^{1}$ Corresponding author: awatson3@unl.edu

Received January 23, 2019.

Accepted February 22, 2019.

Energy lost as methane $\left(\mathrm{CH}_{4}\right)$ by ruminants can range from $2 \%$ to $12 \%$ of total gross energy 
intake (GEI), but is variable depending on diet composition and energy density (Johnson and Johnson, 1995). Production of $\mathrm{CH}_{4}$ is a necessary component of rumen fermentation, but is an energy sink to the animal and has been implicated in global warming (Boadi et al., 2004).

Biochar is produced by burning organic matter (OM; typically plant material) in the absence of oxygen (Hansen et al., 2012). Although biochars' mode of action is not fully understood, suggested mechanisms include biochar adsorbing gas in the rumen resulting in reduced $\mathrm{CH}_{4}$ eructation, the porous nature of biochar increasing inert surface area in the rumen allowing for improved microbial habitat, or altering the microbial community (Leng, 2014; Saleem et al., 2018). Feng et al. (2012) found that biochar increases the ratio of methanotrophs to methanogens in paddy soils, and this process may also occur in the rumen. Feeding biochar has been shown to decrease production of $\mathrm{CH}_{4}$ from in vitro systems for hay (Hansen et al., 2012), cassava root meal-based diets (Leng et al., 2012b), and barley silage diets (Saleem et al., 2018). However, the feedstock and process used to produce the biochar may affect results (Leng et al., 2013; McFarlane et al., 2017). In vivo results of feeding biochar to cattle are limited, Leng et al. (2012a) reported a decrease in $\mathrm{CH}_{4}$ production from cattle fed diets based on cassava root chips and foliage whereas Erickson et al. (2011) measured an increase in diet digestibility when activated carbon was added to poor quality corn silage diets. The objectives of the following experiments were to determine the effects of biochar on $\mathrm{CH}_{4}$ production and diet digestibility in vivo in growing and finishing beef cattle diets composed of feeds commonly used in the Great Plains of the United States.

\section{MATERIALS AND METHODS}

All animal care and management practices were approved by the University of Nebraska-Lincoln Institutional Animal Care and Use Committee (approval number 1282). Because biochar is not currently approved by the U.S. Food and Drug Administration to be fed to cattle entering the human food chain, all cattle were killed under veterinary supervision and composted at completion of the experiments.

\section{Growing Experiment}

An indirect calorimetry study evaluated diet digestibility and $\mathrm{CH}_{4}$ production for growing cattle fed varying inclusions of biochar (High Plains Biochar LLC, Laramie, WY). Biochar was made from whole pine trees, including limbs and needles, using commercial biochar equipment (BioChar King BK 1000; OrganiLock, Inc., Madisonville, KY). Biochar was analyzed for dioxin and furan contaminants using method 1613B (US EPA, 2010; Pace Analytical, Minneapolis, MN), and the presence of polychloro dibenzo- $p$-dioxins and polychloro dibenzofurans was non-detectable with detection minimums of 1 to $10 \mathrm{ng} / \mathrm{kg}$. Method 6010C (US EPA, 2000) was used to measure concentration of cadmium, lead, and arsenic in the biochar, which were all non-detectable with detection minimums of $0.15,0.49$, and $0.98 \mathrm{mg} / \mathrm{kg}$, respectively. Method 7471B (US EPA, 1998) was used to measure concentration of mercury, which was also non-detectable with a detection minimum of $0.02 \mathrm{mg} / \mathrm{kg}$. The biochar had a composition of $85 \%$ carbon, $0.7 \%$ nitrogen, and $94 \%$ OM on a dry matter (DM) basis with a $\mathrm{pH}$ of 8.0 . Particle size distribution was $1.0 \%$ greater than $9.5 \mathrm{~mm}, 18.7 \% 3.35$ to $9.5 \mathrm{~mm}, 44.0 \%$ 1.18 to $3.35 \mathrm{~mm}, 10.8 \% 0.850$ to $1.18 \mathrm{~mm}, 6.8 \%$ 0.600 to $0.850 \mathrm{~mm}$, and $18.7 \%$ less than $0.600 \mathrm{~mm}$.

Six crossbred steers (initial body weight [BW] $529 \mathrm{~kg}$; SD = $16 \mathrm{~kg}$ ) were used in a 6 period repeated switchback design (Cochran and Cox, 1957). Steers were assigned randomly to one of three treatments which alternated over 6 periods; thus, measurements were collected on each animal consuming each treatment during two nonconsecutive experimental periods. Diets fed were identical between treatments other than inclusion of biochar, which displaced fine ground corn in the supplement at $0 \%, 0.8 \%$, or $3 \%$ of diet DM (Table 1 ). Periods ranged from 14 to $24 \mathrm{~d}$ with two consecutive, $23-\mathrm{h}$ periods in a headbox calorimeter. Periods 1, 2, 5, and 6 were $14 \mathrm{~d}$ and periods 3 and 4 were 24 and 21 d, respectively. Availability of the calorimeters dictated period length. Each period consisted of adaptation to treatments (minimum of $8 \mathrm{~d}$ ), fecal grab sampling 4 times/d $(0700,1100,1500$, and $1900 \mathrm{~h})$ on four consecutive d leading up to headbox collections, and headbox collections for the final $2 \mathrm{~d}$ of the period. Individual feed ingredient samples were taken weekly and frozen $\left(-4{ }^{\circ} \mathrm{C}\right)$ until trial completion.

Diets were mixed twice weekly in a stationary ribbon mixer (model HD-5, Davis Precision Horizontal Batch Mixer; H.C Davis Sons Manufacturing Co., Inc., Bonner Springs, KS) and stored in $200 \mathrm{~L}$ barrels. The barrels were stored in a cooler held at $4{ }^{\circ} \mathrm{C}$ to ensure diet quality was maintained. Cattle were fed ad libitum twice daily 
Table 1. Composition of diet (DM basis) fed to cattle (growing experiment)

\begin{tabular}{lccc}
\hline \hline & \multicolumn{3}{c}{ Biochar inclusion, $\%$ DM } \\
\cline { 2 - 4 } Ingredient, \% of diet DM & 0 & 0.8 & 3 \\
\hline Brome hay & 21 & 21 & 21 \\
Wheat straw & 20 & 20 & 20 \\
Corn silage & 30 & 30 & 30 \\
Wet distillers grains plus solubles & 22 & 22 & 22 \\
Supplement ${ }^{1}$ & & & \\
Fine ground corn & 4.630 & 3.830 & 1.630 \\
Biochar & - & 0.800 & 3.000 \\
Limestone & 1.320 & 1.320 & 1.320 \\
Tallow & 0.175 & 0.175 & 0.175 \\
Urea & 0.500 & 0.500 & 0.500 \\
Salt & 0.300 & 0.300 & 0.300 \\
Beef trace mineral ${ }^{2}$ & 0.050 & 0.050 & 0.050 \\
Vitamin A-D-E ${ }^{3}$ & 0.015 & 0.015 & 0.015 \\
Rumensin-90 & 0.010 & 0.010 & 0.010 \\
Nutrient analysis, \% & & & \\
DM & & & \\
OM & 62.1 & 62.5 & 62.7 \\
CP & 90.6 & 90.9 & 90.9 \\
NDF & 13.5 & 13.4 & 13.3 \\
ADF & 52.9 & 53.3 & 54.6 \\
\hline & 35.4 & 35.8 & 37.5 \\
\hline
\end{tabular}

$\mathrm{CP}=$ crude protein

${ }^{1}$ Supplement fed at $7 \%$ of diet DM.

${ }^{2}$ Premix contained $10 \% \mathrm{Mg}, 6 \% \mathrm{Zn}, 2.5 \% \mathrm{Mn}, 0.5 \% \mathrm{Cu}, 0.3 \% \mathrm{I}$, and $0.05 \%$ Co.

${ }^{3}$ Premix contained $1,500 \mathrm{IU}$ of vitamin A, 3,000 IU of vitamin D, and $3.7 \mathrm{IU}$ of vitamin E per gram.

${ }^{4}$ Formulated to supply Rumensin-90 (Elanco Animal Health,; Greenfield, IN) at $20 \mathrm{mg} / \mathrm{kg}$ of DM.

${ }^{5}$ Nutrient analysis was measured on weekly grab samples of individual feeds, composited into period samples.

at 0800 and $1500 \mathrm{~h}$. Steers were individually housed in $1.5 \times 2.4 \mathrm{~m}$ slatted floor pens with rubber mats in a temperature-controlled room $\left(25^{\circ} \mathrm{C}\right)$ and had ad libitum access to water. Feed refusals were weighed back daily and adjustments for feed offered were made accordingly. Feed refusals were weighed, subsampled, and dried at $60{ }^{\circ} \mathrm{C}$ for DM determination during the fecal collection period. Fecal samples were composited by day, freeze-dried, and ground to $1 \mathrm{~mm}$ using a Wiley Mill (Thomas Scientific, Swedesboro, NJ). The ground samples were then composited by period for each steer. Feed samples were also composited by period, freeze-dried and ground to $1 \mathrm{~mm}$. Feed and fecal samples, composited by period, were dried at $100{ }^{\circ} \mathrm{C}$ for $24 \mathrm{~h}$ to determine DM and then burned in a cool muffle furnace at $600{ }^{\circ} \mathrm{C}$ for $6 \mathrm{~h}$ to determine $\mathrm{OM}$.

Feed and fecal samples were also analyzed for neutral detergent fiber (NDF) using the Van Soest et al. (1991) method. Sodium sulfite (0.5 g; Fisher Scientific, Fair Lawn, NJ) was added to the samples before $100 \mathrm{~mL}$ of ND solution (Midland Scientific, Davenport, IA) was added. Alpha-amylase (ANKOM Technology, Macedon, NY) was added at the beginning of boiling and at $30 \mathrm{~min}$ of reflux in $0.5 \mathrm{~mL}$ increments to all fecal, corn silage, wet distillers grains plus solubles, and supplement samples. Feed and fecal samples were analyzed for acid detergent fiber (ADF) using method 973.18 (AOAC International, 2000).

Acid insoluble ash was used as an internal marker to estimate fecal output and diet digestibility. Acid insoluble ash was determined by placing the dried ADF sample into a cool muffle furnace at $600{ }^{\circ} \mathrm{C}$ for $6 \mathrm{~h}$. Fecal output was calculated by dividing acid insoluble ash intake by acid insoluble ash in the feces. Acid insoluble ash analysis was done on the base diet fed, feed refusals, and fecal samples to determine acid insoluble ash intake and fecal output, which was used to determine digestibility. Gross heat energy was determined for feed and fecal samples using a Parr 6400 oxygen bomb calorimeter (Parr Instrument Company, Moline, IL). Digestible energy was then calculated by subtracting total gross fecal energy from total GEI.

\section{Gas Emissions}

$\mathrm{CH}_{4}$ emissions were measured through indirect calorimetry using headboxes built at the University of Nebraska-Lincoln. Three headboxes were available, so timing of measurements was staggered, with each treatment represented during each collection period. Collections consisted of 2 consecutive, $23 \mathrm{~h}$ periods on the final $2 \mathrm{~d}$ of each period. The collection method was similar to that described by Foth et al. (2015). A training period of 2 wk was used prior to the experiment in order for steers to become acclimated to the headboxes, with a gradual increase in amount of time spent in the headboxes. One steer was removed from the gas emissions portion of the trial after period 2 because of a lack of dry matter intake (DMI) while in the headbox. Feed was offered ad libitum while the steers were in the headboxes and was adjusted based off refusals throughout the collection period. Feed was placed in the headbox when the steers entered at $0800 \mathrm{~h}$. The doors were then closed and the vacuum motor (Model 115923; Ametek Lamb Electric, Kent, OH) was turned on, creating a negative pressure system in the headbox. Total airflow through the headbox was measured using a gas meter (Model AL425; American Meter, Horsham, PA), and was regulated by flow meters (Model 1350E Sho-Rate 50; Brooks Instruments, Hatfield, PA) to allow for proportional 
samples to be gathered. The headbox doors were closed 15 min prior to collection starting to allow for several air turnovers before emissions were collected. The samples were collected in foil bags that continuously and evenly filled throughout the $23-\mathrm{h}$ collection period. Two bags per headbox were continuously filled over the 23-h collection, one bag for ambient air entering the headbox and one for emissions leaving the headbox. Air was diverted to each bag using glass tube rotameters (Model 1350E ShoRate "50"; Brooks Instruments). These bags were analyzed for $\mathrm{CH}_{4}$ and carbon dioxide $\left(\mathrm{CO}_{2}\right)$ using a gas chromatograph (Universal Analyzers Inc., Carson City, NV).

After the 23-h collection period, steers were brought back to their pens for $1 \mathrm{~h}$ while feed refusals were collected, rubber mats and waterers were cleaned, foil bags switched out, and flow rates were recorded. A second 23-h collection period then followed. Gas measurements collected over the $2 \mathrm{~d}$ were averaged to obtain one value per period for each steer. Intakes decreased $12 \%$ on average and become more variable when cattle entered the headboxes compared to the $5 \mathrm{~d}$ prior to being in the headboxes. Most of the decrease in intake was on $\mathrm{d} 2$ of the headbox period. Therefore, average DMI for the $5 \mathrm{~d}$ directly prior to the $2 \mathrm{~d}$ headbox period was used to report gas emissions on a grams per kilogram of DMI basis.

\section{Finishing Experiment}

The same six steers were then used in a 3-period crossover design with a finishing diet. Steers remained in the same BW block and were assigned randomly within block to one of three treatments. Similar to the growing experiment, diets fed were identical between treatments other than inclusion of biochar $(0 \%, 0.8 \%$, or $3 \%$ of diet DM), which displaced fine-ground corn in the supplement (Table 2). Periods were $16 \mathrm{~d}$ with two consecutive 23-h headbox collections over the last $4 \mathrm{~d}$ of each period. Because three headboxes were available, headbox collections were done over $4 \mathrm{~d}$ (six total animals for $2 \mathrm{~d}$ each), each treatment was represented in each headbox collection period. Fecal output and diet digestibility were calculated by dosing $10 \mathrm{~g} / \mathrm{d}$ of titanium dioxide in the feed. Feed and fecal sampling and nutrient analysis were all conducted the same as for the growing experiment, with the exception of titanium dioxide instead of acid insoluble ash as the marker to determine diet digestibility. Titanium dioxide analysis on feed and fecal samples was done using methodology from
Table 2. Composition of diet (DM basis) fed to cattle (finishing experiment)

\begin{tabular}{|c|c|c|c|}
\hline \multirow[b]{2}{*}{ Ingredient, $\%$ of diet DM } & \multicolumn{3}{|c|}{ Biochar inclusion, $\%$ DM } \\
\hline & 0 & 0.8 & 3 \\
\hline Dry-rolled corn & 53 & 53 & 53 \\
\hline Corn silage & 15 & 15 & 15 \\
\hline Wet distillers grains plus solubles & 25 & 25 & 25 \\
\hline \multicolumn{4}{|l|}{ Supplement ${ }^{1}$} \\
\hline Fine ground corn & 4.630 & 3.830 & 1.630 \\
\hline Biochar & - & 0.800 & 3.000 \\
\hline Limestone & 1.320 & 1.320 & 1.320 \\
\hline Tallow & 0.175 & 0.175 & 0.175 \\
\hline Urea & 0.500 & 0.500 & 0.500 \\
\hline Salt & 0.300 & 0.300 & 0.300 \\
\hline Beef trace mineral ${ }^{2}$ & 0.050 & 0.050 & 0.050 \\
\hline Vitamin A-D-E ${ }^{3}$ & 0.015 & 0.015 & 0.015 \\
\hline Rumensin- $90^{4}$ & 0.010 & 0.010 & 0.010 \\
\hline \multicolumn{4}{|l|}{ Nutrient analysis, $\%^{5}$} \\
\hline $\mathrm{DM}$ & 66.9 & 67.3 & 67.5 \\
\hline OM & 85.4 & 85.4 & 85.2 \\
\hline $\mathrm{CP}$ & 13.3 & 13.2 & 13.1 \\
\hline NDF & 25.2 & 25.9 & 27.9 \\
\hline $\mathrm{ADF}$ & 10.7 & 11.2 & 12.6 \\
\hline
\end{tabular}

$\mathrm{CP}=$ crude protein

${ }^{1}$ Supplement fed at $7 \%$ of diet DM.

${ }^{2}$ Premix contained $10 \% \mathrm{Mg}, 6 \% \mathrm{Zn}, 2.5 \% \mathrm{Mn}, 0.5 \% \mathrm{Cu}, 0.3 \% \mathrm{I}$, and $0.05 \%$ Co.

${ }^{3}$ Premix contained $1,500 \mathrm{IU}$ of vitamin A, 3,000 IU of vitamin D, and $3.7 \mathrm{IU}$ of vitamin E. per gram.

${ }^{4}$ Formulated to supply Rumensin-90 (Elanco Animal Health) at $20 \mathrm{mg} / \mathrm{kg}$ of DM.

${ }^{5}$ Nutrient analysis was measured on weekly grab samples of individual feeds, composited into period samples.

Myers et al. (2004). Gas emissions were also collected as described in the growing experiment, with all six animals being used.

\section{Statistical Analysis}

Statistical analysis was done using the MIXED procedure of SAS (SAS Inst Inc., Cary, NC) for DM digestibility (DMD) as a $6 \times 6$ balanced replicated Latin rectangle and gas production as an unbalanced replicated Latin rectangle (due to removal of one steer) for the growing experiment and as a $6 \times 3$ balanced Latin rectangle for the finishing experiment. The model included treatment and period as fixed effects for digestibility and gas production analysis. Steer was considered a random effect in both analyses. Orthogonal contrasts were used to detect linear and quadratic relationships for the main effect of biochar inclusion. Because treatments were not evenly spaced, the IML procedure of SAS was used to generate coefficients used for contrast statements. Biochar included vs. biochar 
absent from the diet (i.e. combining the $0.8 \%$ and $3 \%$ treatments) was also analyzed as a preplanned contrast. Probabilities were considered significant at $P<0.10$ and tendencies are discussed at $P \leq 0.15$.

\section{RESULTS AND DISCUSSION}

\section{Growing Experiment}

Digestibility and energy. DMI $(\mathrm{kg} / \mathrm{d})$ did not differ between treatments $(P \geq 0.43$; Table 3$)$, but did increase between periods as a result of the cattle growing, and therefore eating more. This is similar to results reported by Leng et al. (2012a) in which authors fed biochar derived from rice husks to cattle in Laos. These authors conducted a 98-d trial feeding biochar at $0.6 \%$ of the diet $\mathrm{DM}$ in a cassava root chip and cassava foliage-based diet. No differences in DMI were detected, and the authors observed an increase in average daily gain and feed efficiency, but did not report any digestibility measures for the diets fed.

All intake, fecal output and digestibility data are reported in Table 3. A quadratic increase $(P=0.10)$ was observed for OM digestibility (OMD) with the $0.8 \%$ biochar treatment having the greatest

Table 3. Effects of biochar inclusion in cattle diets on intake and total tract digestibility (growing experiment)

\begin{tabular}{|c|c|c|c|c|c|c|}
\hline \multirow[b]{2}{*}{ Item } & \multicolumn{3}{|c|}{$\begin{array}{c}\text { Biochar inclusion, } \\
\% \text { DM }\end{array}$} & \multirow[b]{2}{*}{ SEM } & \multicolumn{2}{|c|}{$P$-values ${ }^{1}$} \\
\hline & 0 & 0.8 & 3 & & Lin & Quad \\
\hline \multicolumn{7}{|l|}{$\overline{\mathrm{DM}}$} \\
\hline Intake, $\mathrm{kg} / \mathrm{d}$ & 8.01 & 7.88 & 7.83 & 0.21 & 0.43 & 0.64 \\
\hline Excreted, $\mathrm{kg} / \mathrm{d}$ & 3.57 & 3.35 & 3.57 & 0.16 & 0.71 & 0.18 \\
\hline Digestibility, \% & 55.7 & 57.6 & 54.7 & 1.12 & 0.25 & 0.11 \\
\hline \multicolumn{7}{|l|}{ OM } \\
\hline Intake, $\mathrm{kg} / \mathrm{d}$ & 7.25 & 7.16 & 7.12 & 0.19 & 0.52 & 0.74 \\
\hline Excreted, $\mathrm{kg} / \mathrm{d}$ & 3.02 & 2.83 & 3.03 & 0.14 & 0.68 & 0.18 \\
\hline Digestibility, \% & 58.6 & 60.6 & 57.7 & 1.16 & 0.31 & 0.10 \\
\hline \multicolumn{7}{|l|}{ NDF } \\
\hline Intake, $\mathrm{kg} / \mathrm{d}$ & 4.24 & 4.19 & 4.28 & 0.11 & 0.62 & 0.57 \\
\hline Excreted, $\mathrm{kg} / \mathrm{d}$ & 2.11 & 2.00 & 2.24 & 0.11 & 0.14 & 0.16 \\
\hline Digestibility, \% & 50.5 & 52.6 & 48.2 & 1.55 & 0.08 & 0.10 \\
\hline \multicolumn{7}{|l|}{$\mathrm{ADF}$} \\
\hline Intake, $\mathrm{kg} / \mathrm{d}$ & 2.83 & 2.82 & 2.93 & 0.08 & 0.13 & 0.53 \\
\hline Excreted, $\mathrm{kg} / \mathrm{d}$ & 1.52 & 1.47 & 1.63 & 0.08 & 0.16 & 0.33 \\
\hline Digestibility, \% & 46.7 & 48.1 & 45.0 & 1.50 & 0.29 & 0.35 \\
\hline \multicolumn{7}{|l|}{ Energy } \\
\hline GEI, Mcal/d & 35.3 & 34.8 & 34.8 & 0.93 & 0.62 & 0.68 \\
\hline Fecal Energy, Mcal/d & 14.8 & 13.8 & 14.8 & 0.68 & 0.67 & 0.13 \\
\hline DEI, Mcal/d & 20.5 & 21.0 & 20.0 & 0.51 & 0.27 & 0.30 \\
\hline DEI, Mcal/kg DMI & 2.57 & 2.68 & 2.56 & 0.05 & 0.52 & 0.08 \\
\hline
\end{tabular}

${ }^{1}$ Linear and quadratic orthogonal polynomial contrasts.
OMD $(60.6 \%)$. Similarly, DMD tended $(P=0.11)$ to increase quadratically. A linear decrease $(P=0.08)$ was observed for NDF digestibility (NDFD) with $3 \%$ inclusion of biochar having the lowest digestibility (48.2\%). GEI (Mcal/d) and digestible energy intake (DEI; Mcal/d) did not differ between treatments ( $P \geq 0.27)$; however, DEI as Mcal $/ \mathrm{kg}$ of DMI had a quadratic increase $(P=0.08)$ with $0.8 \%$ inclusion of biochar being the greatest at $2.68 \mathrm{Mcal} /$ $\mathrm{kg}$ DMI. A tendency was observed for a linear increase in NDF excretion $(P=0.14)$ and ADF intake $(P=0.13)$, whereas energy excreted $(\mathrm{Mcal} / \mathrm{d})$ tended to decrease quadratically $(P=0.13)$.

Van et al. (2006) fed a charcoal product derived from bamboo to goats on an acacia foliage and para grass-based diet in Vietnam at inclusions of 0 , 1 , and $1.5 \mathrm{~g}$ per $\mathrm{kg}$ of BW. These authors reported that bamboo charcoal did not affect DMI, and improved DMD and OMD values for the 0.5 and $1 \mathrm{~g} /$ $\mathrm{kg}$ BW treatments compared to the control and $1.5 \mathrm{~g} / \mathrm{kg} \mathrm{BW}$ treatment. The authors attributed the digestibility improvements to the ability of the charcoal to adsorb toxins and tannins, preventing them from reaching the intestines and inhibiting enzyme excretion, resulting in more digestion. However, Kutlu et al. (2001) reported that wood-based biochar products are capable of adsorbing vitamins, fats, and enzymes when included at a high level in poultry diets, which could explain some of the digestibility responses observed in the present trial for the 3\% biochar treatment. Saleem et al. (2018) reported a linear increase in DM, OM, crude protein, ADF, and NDFD with the inclusion of $0 \%$, $0.5 \%, 1 \%$, and $2 \%$ biochar to a forage-based $(60 \%$ barley silage) diet using an artificial rumen system.

$\mathrm{CH}_{4}$ and $\mathrm{CO}_{2}$ production. Reported DMI $(\mathrm{kg} / \mathrm{d})$ used for gas emission calculations was a $5 \mathrm{~d}$ average prior to cattle entering the headboxes, and was not different between treatments $(P \geq 0.68$; Table 4). The GEI and DEI (Mcal/d) based on the $5 \mathrm{~d}$ intakes were also not different $(P \geq 0.32) . \mathrm{CH}_{4}$ production $(\mathrm{g} / \mathrm{d})$ tended $(P=0.14)$ to decrease quadratically with the $0.8 \%$ biochar treatment having the lowest $\mathrm{CH}_{4}$ output at $97.2 \mathrm{~g} / \mathrm{d}$. When combining the two treatments that contained biochar $(0.8 \%$ and $3 \%)$ into one to compare to the $0 \%$ treatment, $\mathrm{CH}_{4}$ production $(\mathrm{g} / \mathrm{d})$ tended $(P=0.11)$ to be lower for the biochar cattle relative to the control cattle. Saleem et al. (2018) also reported a quadratic response for $\mathrm{CH}_{4}$ production $(\mathrm{mg} / \mathrm{d}$ and $\mathrm{g} / \mathrm{g}$ of $\mathrm{DM}$ incubated) with $0.5 \%$ biochar having the least $\mathrm{CH}_{4}$ production. In the current study, the $0.8 \%$ biochar treatment reduced $\mathrm{CH}_{4}$ (g/d) by $11 \%$ compared to the control treatment 
Table 4. Effects of increasing inclusion of biochar on $\mathrm{CH}_{4}$ and $\mathrm{CO}_{2}$ emissions from steers (growing experiment)

\begin{tabular}{|c|c|c|c|c|c|c|c|}
\hline & \multicolumn{3}{|c|}{$\begin{array}{c}\text { Biochar inclusion, } \\
\% \mathrm{DM}\end{array}$} & \multirow[b]{2}{*}{ SEM } & \multicolumn{3}{|c|}{$P$-values ${ }^{1}$} \\
\hline & 0 & 0.8 & 3 & & Lin & Quad & $\mathrm{Y} / \mathrm{N}$ \\
\hline$\overline{\mathrm{DMI}}, \mathrm{kg} / \mathrm{d}$ & 7.91 & 7.90 & 7.84 & 0.21 & 0.68 & 0.90 & 0.70 \\
\hline GEI, Mcal/d & 34.9 & 34.7 & 34.8 & 0.94 & 0.99 & 0.85 & 0.88 \\
\hline DEI, Mcal/d & 20.6 & 21.1 & 20.3 & 0.53 & 0.50 & 0.32 & 0.82 \\
\hline \multicolumn{8}{|l|}{$\mathrm{CH}_{4}$} \\
\hline $\mathrm{g} / \mathrm{d}$ & 109 & 97.2 & 100 & 5.1 & 0.42 & 0.14 & 0.11 \\
\hline g/kg DMI & 13.7 & 12.4 & 12.7 & 0.60 & 0.43 & 0.18 & 0.13 \\
\hline g/Mcal & 3.10 & 2.80 & 2.86 & 0.13 & 0.37 & 0.17 & 0.11 \\
\hline \multicolumn{8}{|l|}{ GEI } \\
\hline g/Mcal DEI & 5.27 & 4.62 & 4.92 & 0.21 & 0.51 & 0.05 & 0.07 \\
\hline \multicolumn{8}{|l|}{$\mathrm{CO}_{2}$} \\
\hline $\mathrm{g} / \mathrm{d}$ & 5549 & 5051 & 5163 & 172 & 0.19 & 0.05 & 0.02 \\
\hline $\mathrm{g} / \mathrm{kg}$ DMI & 702 & 644 & 660 & 18.1 & 0.27 & 0.06 & 0.03 \\
\hline $\mathrm{CH}_{4}: \mathrm{CO}_{2}$ & 0.020 & 0.019 & 0.019 & 0.001 & 0.67 & 0.70 & 0.56 \\
\hline
\end{tabular}

${ }^{1}$ Linear and quadratic orthogonal polynomial contrasts. $\mathrm{Y} / \mathrm{N}=$ biochar inclusion in diet $(0.8 \%$ and $3 \%$ treatments combined) vs. no biochar in diet ( 0 treatment).

without biochar. This is a smaller response than Leng et al. (2012a) reported with a $24 \%$ reduction in $\mathrm{CH}_{4}$ (ppm) when feeding biochar derived from rice hulls at $0.6 \%$ of the diet DM. Similarly, Saleem et al. (2018) reported a $25 \%$ reduction in $\mathrm{CH}_{4}(\mathrm{mg} / \mathrm{d})$ from an artificial rumen system with $0.5 \%$ biochar compared to no biochar.

$\mathrm{CH}_{4}$ production measured as $\mathrm{g} / \mathrm{kg}$ DMI was not different between treatments in the present study $(P$ $\geq 0.18$ ). When analyzing $\mathrm{CH}_{4}$ produced per Mcal of GEI, no differences were observed between treatments $(P \geq 0.17)$; however, $\mathrm{CH}_{4}$ per Mcal of DEI was lowest for $0.8 \%$ biochar $(4.62 \mathrm{~g} / \mathrm{Mcal}$ DEI) and greatest for the $0 \%$ treatment $(5.27 \mathrm{~g} / \mathrm{Mcal} \mathrm{DEI})$, resulting in a quadratic response $(P=0.05)$. When combining treatments, $\mathrm{CH}_{4}$ as $\mathrm{g} / \mathrm{kg} \mathrm{DMI}(P=0.13)$ and per Mcal of GEI tended $(P=0.11)$ to be reduced for the biochar treatments compared to the control whereas $\mathrm{CH}_{4}$ per Mcal of DEI was reduced $(P=0.07)$ for the biochar cattle.

$\mathrm{CO}_{2}$ production $(\mathrm{g} / \mathrm{d})$ was affected by treatment with $0 \%$ biochar having the greatest $\mathrm{CO}_{2}$ production $(5549 \mathrm{~g} / \mathrm{d})$ and $0.8 \%$ biochar reducing $\mathrm{CO}_{2}$ production the most, resulting in a quadratic decrease $(P=0.05)$. This trend continued for $\mathrm{CO}_{2}$ per $\mathrm{kg}$ of DMI with $0.8 \%$ biochar reducing $\mathrm{CO}_{2}$ the most creating a quadratic response $(P=0.06)$. $\mathrm{CO}_{2}$ production was also reduced $(P \leq 0.03 ; \mathrm{g} / \mathrm{d}$ and $\mathrm{g} / \mathrm{kg}$ of DMI) with the inclusion of biochar when analyzed as two treatments, with or without biochar. Adding biochar to the diet likely displaces fermentable substrate, which could result in lower $\mathrm{CO}_{2}$ production.
Leng et al. (2012a) reported greater $\mathrm{CO}_{2}$ production from the biochar treatment relative to the control, which differs from the present trial, but did not suggest why this may have occurred. These same authors reported a lower $\mathrm{CO}_{2}: \mathrm{CH}_{4}$ ratio for the biochar-fed cattle; however, in the present study the ratio was not affected by treatment $(P \geq 0.67)$. McFarlane et al. (2017) reported an increase in total gas production from an in vitro system when biochar was added to an orchard grass hay diet, but no differences were measured in volatile fatty acid concentration or ratio of acetate:propionate.

The reduction in $\mathrm{CH}_{4}$ production reported by Leng et al. (2012a) and Saleem et al. (2018) was not observed to the same extent in the present study. Those authors reported a $24 \%$ to $25 \%$ reduction in $\mathrm{CH}_{4}$ when feeding biochar at $0.5 \%$ to $0.6 \%$ of the diet. In the current trial, with all three treatments analyzed, $\mathrm{CH}_{4}$ production was not statistically reduced. However, $\mathrm{CH}_{4}$ reported as $\mathrm{g} / \mathrm{d}$ and $\mathrm{g} / \mathrm{kg}$ DMI tended $(P \leq 0.13)$ to be reduced by biochar inclusion, $9.1 \%$ and $8.4 \%$, respectively, when analyzed as two treatments, with and without biochar in the diet. Leng et al. (2012a) observed a 13\% increase in $\mathrm{CO}_{2}$ (ppm) when including biochar in the diet. $\mathrm{CO}_{2}$ production was reduced approximately $8 \%$ in the current trial.

There could be many reasons for the different magnitude of results observed between the present trial and results reported by Leng et al. (2012a), including cattle breed, cattle size, diet consumed, and collection method. These authors reported that the 12 "Yellow" cattle they used had an initial BW of 80 to $100 \mathrm{~kg}$, whereas in the present trial the cattle used were roughly five times that size. Rumen function and microbial population within the rumen certainly vary between cattle that are of different breed and size with differing diets and intakes, which could influence the results reported. Specific genera of bacteria and archaea have been shown to be correlated with $\mathrm{CH}_{4}$ production, although how these microbial populations are modulated within the rumen is quite complex (Cunha et al., 2017). Leng et al. (2012a) fed a diet consisting of $61 \%$ cassava root chips and $36 \%$ cassava foliage. Cassava root is high in soluble carbohydrates and low in fiber (Oguntimein, 1988). Diet composition and quality can greatly impact $\mathrm{CH}_{4}$ emissions, with estimates of $3.5 \%$ of GEI lost as $\mathrm{CH}_{4}$ for concentrate-fed cattle and $6 \%$ of GEI for forage-fed cattle (Beauchemin and McGinn, 2006). In the Leng et al. (2012a) study authors used a short-term collection method for measuring respired air (once for 5 min in a headbox) and calculated $\mathrm{CH}_{4}$ production 
as described by Madsen et al. (2010). Intake drives $\mathrm{CH}_{4}$ production, so short-term measurements are variable depending on time of gas collection relative to feeding.

The silage-based diet fed by Saleem et al. (2018) was similar to the diet fed in the current trial, but NDF and ADF content were lower. Using an artificial rumen system allows for greater control over intake, $\mathrm{pH}$, passage rate, and other digestion parameters than measuring digestion in vivo, but does not perfectly replicate the animal. Results of our in vivo study matchup well with Saleem et al. (2018) in vitro study, although the magnitude of differences between treatments differ.

\section{Finishing Experiment}

Digestibility and energy. Intake of DM, OM, $\mathrm{NDF}$, and ADF all increased in a bell-shaped curve $(P \leq 0.10)$ as biochar inclusion in the diet increased (Table 5). DMD and OMD tended to decrease linearly $(P \leq 0.14)$ as biochar inclusion increased, whereas acid detergent fiber digestibility decreased linearly $(P \leq 0.10)$ as biochar inclusion increased. A linear increase $(P \leq 0.07)$ in fecal ADF and fecal NDF was observed as biochar inclusion increased.

As biochar inclusion in the diet increased, GEI quadratically increased $(P=0.07)$, with $0.8 \%$ biochar having the greatest GEI (59.2 Mcal/d). Fecal energy $(\mathrm{Mcal} / \mathrm{d})$ linearly increased $(P=0.09)$ and DEI (Mcal/kg DMI) linearly decreased $(P=0.10)$ as biochar inclusion increased. There are limited data available on the impacts of biochar inclusion in finishing or high concentrate diets. Most previous research has focused on forage-based diets (Hansen et al., 2012; Leng et al. 2012a; Saleem et al. 2018). Erickson et al. (2011) fed 0, 20, or $40 \mathrm{~g} / \mathrm{d}$ of an acidwashed activated carbon product made from lignite coal to dairy cows on a corn silage-based diet in two experiments. When poor quality corn silage was fed, the addition of activated carbon increased DMI and NDFD. However, when good quality corn silage was fed, no differences were measured with the inclusion of biochar. The activated carbon product fed by Erickson et al. (2011) may have had different physical and chemical properties than the biochar fed in the current study.

$\mathrm{CH}_{4}$ and $\mathrm{CO}_{2}$ production. Reported DMI used for gas emission calculations increased quadratically $(P=0.01$; Table 6$)$ as biochar inclusion increased. When biochar treatments $(0.8 \%$ and $3 \%)$ were combined, biochar cattle had greater DMI $(P=0.04)$ compared to the control. Both GEI and
Table 5. Effects of biochar inclusion in cattle diets on intake and total tract digestibility (finishing experiment)

\begin{tabular}{|c|c|c|c|c|c|c|}
\hline \multirow[b]{2}{*}{ Item } & \multicolumn{3}{|c|}{$\begin{array}{c}\text { Biochar inclusion, } \\
\% \mathrm{DM}\end{array}$} & \multirow[b]{2}{*}{ SEM } & \multicolumn{2}{|c|}{$P$-value ${ }^{1}$} \\
\hline & 0 & 0.8 & 3 & & Lin & Quad \\
\hline \multicolumn{7}{|l|}{$\overline{\mathrm{DM}}$} \\
\hline Intake, $\mathrm{kg} / \mathrm{d}$ & 12.0 & 12.9 & 12.1 & 0.51 & 0.84 & 0.07 \\
\hline Excreted, $\mathrm{kg} / \mathrm{d}$ & 3.40 & 3.90 & 3.82 & 0.19 & 0.18 & 0.08 \\
\hline Digestibility, \% & 71.5 & 70.0 & 68.2 & 1.54 & 0.14 & 0.74 \\
\hline \multicolumn{7}{|l|}{$\mathrm{OM}$} \\
\hline Intake, $\mathrm{kg} / \mathrm{d}$ & 10.2 & 11.1 & 10.4 & 0.43 & 0.81 & 0.06 \\
\hline Excreted, $\mathrm{kg} / \mathrm{d}$ & 2.78 & 3.30 & 3.20 & 0.18 & 0.18 & 0.07 \\
\hline Digestibility, \% & 72.8 & 70.4 & 68.7 & 1.65 & 0.13 & 0.52 \\
\hline \multicolumn{7}{|l|}{$\mathrm{NDF}$} \\
\hline Intake, $\mathrm{kg} / \mathrm{d}$ & 3.02 & 3.35 & 3.38 & 0.14 & 0.05 & 0.09 \\
\hline Excreted, $\mathrm{kg} / \mathrm{d}$ & 1.30 & 1.55 & 1.56 & 0.10 & 0.07 & 0.08 \\
\hline Digestibility, \% & 56.6 & 54.2 & 53.4 & 3.37 & 0.39 & 0.59 \\
\hline \multicolumn{7}{|l|}{$\mathrm{ADF}$} \\
\hline Intake, $\mathrm{kg} / \mathrm{d}$ & 1.28 & 1.45 & 1.53 & 0.06 & 0.01 & 0.10 \\
\hline Excreted, $\mathrm{kg} / \mathrm{d}$ & 0.61 & 0.73 & 0.89 & 0.04 & $<0.01$ & 0.18 \\
\hline Digestibility, $\%$ & 52.4 & 50.1 & 41.3 & 3.05 & $<0.01$ & 0.77 \\
\hline \multicolumn{7}{|l|}{ Energy } \\
\hline GEI, Mcal/d & 54.5 & 59.2 & 55.7 & 2.35 & 0.97 & 0.07 \\
\hline Fecal energy, Mcal/d & 15.2 & 17.6 & 17.9 & 0.97 & 0.09 & 0.28 \\
\hline DEI, Mcal/d & 39.3 & 41.6 & 37.8 & 2.12 & 0.35 & 0.25 \\
\hline DEI, Mcal/kg DMI & 3.29 & 3.22 & 3.10 & 0.08 & 0.10 & 0.87 \\
\hline
\end{tabular}

${ }^{1}$ Linear and quadratic orthogonal polynomial contrasts.

DEI (Mcal/d) based on the 5-d headbox DMI increased quadratically $(P \leq 0.01)$ as biochar inclusion increased. GEI was greater for biochar-fed cattle $(P=0.02)$ compared to the control.

$\mathrm{CH}_{4}$ production (g/d and $\mathrm{g} / \mathrm{kg}$ DMI) was not different between treatments $(P \geq 0.22)$ when analyzed as three treatments or as biochar inclusion vs. no biochar inclusion (Table 6). However, $\mathrm{CH}_{4}$ production (g/d) numerically decreased $9.6 \%$ and $\mathrm{CH}_{4}$ production $(\mathrm{g} / \mathrm{kg}$ DMI) numerically decreased $18.4 \%$ for the $0.8 \%$ biochar treatment relative to no biochar. There were no differences because of treatment in $\mathrm{CH}_{4}$ production relative to GEI or DEI $(P \geq 0.20)$.

$\mathrm{CO}_{2}$ production $(\mathrm{g} / \mathrm{d}$ and $\mathrm{g} / \mathrm{kg} \mathrm{DMI})$ was not different between treatments $(P \geq 0.34)$ when analyzed as three treatments or as biochar inclusion vs. no biochar inclusion. $\mathrm{CO}_{2}$ production $(\mathrm{g} / \mathrm{kg} \mathrm{DMI})$ was numerically reduced $9.9 \%$ for the $0.8 \%$ biochar treatment compared to the control. The ratio of $\mathrm{CH}_{4}$ to $\mathrm{CO}_{2}$ was not affected by treatment $(P \geq$ 0.39 ). Only 3 periods of data were collected in the finishing experiment ( 6 periods in the growing experiment) because of cattle becoming too large for the headboxes, which limited statistical power. 
Table 6. Effects of increasing inclusion of biochar in cattle diets on $\mathrm{CH}_{4}$ and $\mathrm{CO}_{2}$ emissions from steers (finishing experiment)

\begin{tabular}{|c|c|c|c|c|c|c|c|}
\hline \multirow[b]{2}{*}{ Item } & \multicolumn{3}{|c|}{$\begin{array}{c}\text { Biochar inclusion, } \\
\% \mathrm{DM}\end{array}$} & \multirow[b]{2}{*}{ SEM } & \multicolumn{3}{|c|}{$P$-values ${ }^{1}$} \\
\hline & 0 & 0.8 & 3 & & Lin & Quad & $\mathrm{Y} / \mathrm{N}$ \\
\hline DMI, kg/d & 11.3 & 12.7 & 11.9 & 0.50 & 0.52 & 0.01 & 0.04 \\
\hline GEI, Mcal/d & 51.2 & 58.4 & 54.9 & 2.28 & 0.36 & 0.01 & 0.02 \\
\hline DEI, Mcal/d & 37.0 & 41.0 & 37.3 & 1.57 & 0.52 & 0.01 & 0.20 \\
\hline \multicolumn{8}{|l|}{$\mathrm{CH}_{4}$} \\
\hline $\mathrm{g} / \mathrm{d}$ & 141 & 128 & 122 & 13.9 & 0.39 & 0.62 & 0.32 \\
\hline g/kg DMI & 12.5 & 10.2 & 10.6 & 1.46 & 0.51 & 0.32 & 0.22 \\
\hline g/Mcal GEI & 2.74 & 2.21 & 2.31 & 0.32 & 0.47 & 0.30 & 0.20 \\
\hline g/Mcal DEI & 3.80 & 3.15 & 3.41 & 0.46 & 0.71 & 0.35 & 0.33 \\
\hline \multicolumn{8}{|l|}{$\mathrm{CO}_{2}$} \\
\hline $\mathrm{g} / \mathrm{d}$ & 8204 & 8402 & 7755 & 558 & 0.50 & 0.66 & 0.86 \\
\hline $\mathrm{g} / \mathrm{kg}$ DMI & 737 & 664 & 664 & 61.4 & 0.52 & 0.51 & 0.34 \\
\hline $\mathrm{CH}_{4}: \mathrm{CO}_{2}$ & 0.017 & 0.016 & 0.016 & 0.0019 & 0.56 & 0.56 & 0.39 \\
\hline
\end{tabular}

${ }^{1}$ Linear and quadratic orthogonal polynomial contrasts. $\mathrm{Y} / \mathrm{N}=$ biochar inclusion in diet $(0.8 \%$ and $3 \%$ treatments combined) vs. no biochar in diet (0 treatment).

The effect of biochar on $\mathrm{CH}_{4}$ production from ruminants has not been explored in depth, but has shown promise as a potential mitigation strategy. Hansen et al. (2012) and Leng et al. (2012b) both reported $10 \%$ to $17 \%$ reductions in $\mathrm{CH}_{4}$ emissions from in vitro systems when biochar was included, although Hansen et al. (2012) did not report statistically significant differences. Saleem et al. (2018) reported a linear increase in digestibility of DM, $\mathrm{OM}, \mathrm{ADF}$, and NDF with a $25 \%$ reduction in $\mathrm{CH}_{4}$ production when adding $0.5 \%$ engineered biocarbon to an artificial rumen system. Biochar used in the Hansen et al. (2012) and Saleem et al. (2018) studies was made from wood or straw whereas biochar was derived from rice husks in the Leng et al. (2012a, 2012b, 2013) studies. In vitro runs are variable and do not replicate what happens inside the animal perfectly as there are sources of error involved in the procedure. For this reason, the in vivo experiments were conducted. Although not always statistically significant, there were consistent numerical decreases in $\mathrm{CH}_{4}$ production with $0.8 \%$ biochar inclusion in the diet compared to no biochar. Intake was not hindered with biochar inclusion, and actually increased in the finishing experiment. Feeding $0.8 \%$ biochar appears to be sufficient and no further benefits were observed from increasing inclusion to $3 \%$ of diet DM. The effects of biochar in the rumen show promise, but are not fully understood and performance data (BW gain, efficiency, and carcass data) are needed to determine if it is a feasible $\mathrm{CH}_{4}$ mitigation tool for beef cattle.

\section{ACKNOWLEDGMENTS}

This project was funded by the Nebraska Forest Service through the On-Farm/Alternative Wood Use Program. This project was also partially supported by the Nebraska Agricultural Experiment Station with funding from the Hatch Act (1007896) through the USDA National Institute of Food and Agriculture. The authors wish to express gratitude to Rowdy Yeatts (High Plains Biochar LLC, Laramie, WY) for providing biochar.

Conflict of interest statement. None declared.

\section{LITERATURE CITED}

AOAC International. 2000. Official methods of analysis. Vol. 1 and 2. 17th ed. Gaithersburg (MD): AOAC International.

Beauchemin, K. A., and S. M. McGinn. 2006. Methane emissions from beef cattle: effects of fumaric acid, essential oil, and canola oil. J. Anim. Sci. 84:1489-1496. doi: $10.2527 / 2006.8461489 x$

Boadi, D., C. Benchaar, J. Chiquette, and D. Masse. 2004. Mitigation strategies to reduce enteric methane emissions from dairy cows: update review. Can. J. Anim. Sci. 84:319335. doi:10.4141/A03-109

Cochran, W., and G. M. Cox. 1957. Experimental Designs. 2nd ed. New York (NY): John Wiley Sons Inc.

Cunha, C. S., C. M. Veloso, M. I. Marcondes, H. C. Mantovani, T. R. Tomich, L. G. R. Pereira, M. F. L. Ferreira, K. A. Dill-McFarland, and G. Suen. 2017. Assessing the impact of rumen microbial communities on methane emissions and production traits in Holstein cows in a tropical climate. Syst. Appl. Microbiol. 40:492-499. doi:10.1016/j. syapm.2017.07.008

Erickson, P. S., N. L. Whitehouse, and M. L. Dunn. 2011. Activated carbon supplementation of dairy cow diets: effects on apparent total tract nutrient digestibility and taste preference. Prof. Anim. Sci. 27:428-434. doi:10.15232/ S1080-7446(15)30515-5

Feng, Y., Y. Xu, Y. Yu, Z. Xie, and X. Len. 2012. Mechanisms of biochar decreasing methane emissions from Chinese paddy soils. J. Soil. Biol. Biochem. 46:80-88. doi:10.1016/j. soilbio.2011.11.016

Foth, A. J., T. Brown-Brandl, K. J. Hanford, P. S. Miller, G. Garcia Gomez, and P. J. Kononoff. 2015. Energy content of reduced-fat dried distillers grains with solubles for lactating dairy cows. J. Dairy Sci. 98:7142-7152. doi:10.3168/ jds.2014-9226.

Hansen, H. H., I. M. L. D. Storm, and A. M. Sell. 2012. Effect of biochar on in vitro rumen methane production. Acta. Agric. Scand. A Anim. Sci. 62:305-309. doi:10.1080/0906 4702.2013.789548

Johnson, K. A., and D. E. Johnson. 1995. Methane emissions from cattle. J. Anim. Sci. 73:2483-2492. doi: $10.2527 / 1995.7382483 x$

Kutlu, H. R., I. Unsal, and M. Gorgulu. 2001. Effects of providing dietary wood (oak) to broiler chicks and laying hens. Anim. Feed Sci. Technol. 90:213-226. doi:10.1016/ S0377-8401(01)00205-X 
Leng, R. A. 2014. Interactions between microbial consortia in biofilms: a paradigm shift in rumen microbial ecology and enteric methane mitigation. Anim. Prod. Sci. 54:519-543. doi:10.1071/AN13381

Leng, R. A., S. Inthapanya, and T. R. Preston. 2013. All biochars are not equal in lowering methane production in in vitro rumen incubations. Livestock Res. Rural Develop. 25:106. Available from http://www.lrrd.org//rrd25/6/ leng25106.htm

Leng, R. A., T. R. Preston, and S. Inthapanya. 2012a. Biochar reduces enteric methane and improves growth and feed conversion in local "Yellow" cattle fed cassava root chips and fresh cassava foliage. Livestock Res. Rural Develop. 24:199. . Available from http://www.lrrd.org/lrrd24/ 11/leng24199.htm

Leng, R. A., T. R. Preston, and S. Inthapanya. 2012b. Biochar lowers net methane production from rumen fluid in vitro. Livestock Res. Rural Developt. 24:103. Available from http://www.lrrd.org/lrrd24/6/sang24103.htm

Madsen, J., B. S. Bjerg, T. Hvelplund, M. R. Weisbjerg, and P. Lund. 2010. Methane and carbon dioxide ratio in excreted air for quantification of the methane production from ruminants. Livestock Sci. 129:223-227. doi:10.1016/j. livsci.2010.01.001

McFarlane, Z. D., P. R. Myer, E. R. Cope, N. D. Evans, T. C. Bone, B. E. Biss, and J. T. Mulliniks. 2017. Effect of biochar type and size on in vitro rumen fermentation of orchard grass hay. Agric. Sci. 8:316-325. doi:10.4236/sd.2017.84023

Myers, W. D., P. A. Ludden, V. Nayigihugu, and B. W. Hess. 2004. Technical note: a procedure for the preparation and quantitative analysis of samples for titanium dioxide. $\mathrm{J}$. Anim. Sci. 82:179-183. doi:10.2527/2004.821179x

Saleem, A. M., G. O. Ribeiro, Jr, W. Z. Yang, T. Ran, K. A. Beauchemin, E. J. McGeough, K. H. Ominski, E. K. Okine, and T. A. McAllister. 2018. Effect of engineered biocarbon on rumen fermentation, microbial protein synthesis, and methane production in an artificial rumen (RUSITEC) fed a high forage diet. J. Anim. Sci. 96:3121-3130. doi:10.1093/jas/sky204.

Oguntimein, G. B. 1988. Processing cassava for animal feeds. In S. K. Hahn, L. Reynolds and G. N. Egbunike, editors. Cassava as livestock feed in Africa. Proceedings of the IITA (Ibadan, Nigeria)/ILCA (Addis Ababa, Ethiopia)/ University of Ibadan workshop. International Livestock Centre for Africa. Available at: https://cgspace.cgiar.org/ handle/10568/16475.

US EPA. 1998. Mercury or solid or semisolid waste (manual cold-vapor technique). US EPA Region II data validation SOP for EPA method 7471, Revision B. Available from https://www.epa.gov/sites/production/files/2015-07/documents/epa-7471b.pdf.

US EPA. 2000. Inductively coupled plasma-atomic emission spectrometry. US EPA Region II data validation SOP for EPA method 6010, Revision C. Available from https:// www.epa.gov/sites/production/files/2015-07/documents/ epa-6010c.pdf.

US EPA. 2010. Tetra through Octa chlorinated dioxins and furans by isotope dilution (HRGC/HRMS). US EPA Region II data validation SOP for EPA method 1613, Revision B. Available from https://www.epa.gov/sites/ production/files/2017-02/documents/sop_hwss_25_revision_3.pdf.

Van, D. T. T., T. M. Nguyen, and I. Ledin. 2006. Effect of method of processing foliage of Acacia mangium and inclusion of bamboo charcoal in the diet on performance of growing goats. Anim. Feed Sci. Technol. 130:242-256. doi:10.1016/j.anifeedsci.2006.01.008

Van Soest, P. J., J. B. Robertson, and B. A. Lewis. 1991. Methods for dietary fiber, neutral detergent fiber, and nonstarch polysaccharides in relation to animal nutrition. J. Dairy Sci. 74:3583-3597. doi:10.3168/jds.S0022-0302(91)78551-2 